\title{
Identifying Lychee Cultivars by Isozyme Analysis
}

\author{
C. Degani, A. Beiles', R. El-Batsri, M. Goren, and S. Gazit ${ }^{2}$ \\ Institute of Horticulture, Agricultural Research Organization, The Volcani Center, Bet Dagan, Israel
}

Additional index words. Litchi chinensis. electrophoresis, polymorphism, germplasm

\begin{abstract}
Leaf isozyme banding patterns were studied in $\mathbf{3 0}$ cultivars and selections of lychee (Litchi Chinensis Sonn.) by means of starch gel electrophoresis. Polymorphism in aconitase, aspartate aminotransferase, isocitrate dehydrogenase, phosphoglucomutase, shikimate dehydrogenase, superoxide dismutase and triosephosphate isomerase is demonstrated for the first time and observations are extended for the previously described polymorphism in phosphoglucose isomerase. In this study we found five groups of cultivars with identical electrophoretic genotypes. The 18 different cultivars were clustered by the UPGMA method into two large clusters and three pairs of similar cultivars. Three cultivars were relatively separate from the clusters. This study shows that isozyme polymorphism is a prevalent phenomenon in lychee, and that isozymes can provide useful genetic markers for lychee cultivar identification and parental analysis.
\end{abstract}

Lychee, a member of the Sapindaceae family, originated in China and as a cultivated plant has became widely distributed in the tropics and subtropics (Knight, 1980). In the course of its dissemination, some of the Chinese cultivars were misidentified or renamed, creating confusion in the nomenclature of lychee cultivars. The same cultivar may be known under different names in different countries (and even within a given country), and different cultivars sometimes appear under the same name (Menzel and Simpson, 1990).

The utility of using morphological traits for cultivar identification is limited due to the interaction with the environmental conditions (Nielsen, 1985). It is therefore important to have genetic markers for lychee cultivar indentification and verification. Isozymes are convenient and reliable genetic markers because they exhibit codominant expression and do not show environmental effects (Torres and Bergh, 1980). Isozymes have been used to identify cultivars of various fruit trees, including apple (Weeden and Lamb, 1985), avocado (Goldring et al., 1985; Torres and Bergh, 1980), grape (Parfitt and Arulsekar, 1989), kiwi fruit (Messina et al., 1991), loquat (Degani and Blumenfeld, 1986), and mango (Degani et al.. 1990).

Recently, we reported polymorphism of phosphoglucose isomerase (PGI) isozyme system and demonstrated its use for the unequivocal identification of selfed or outcrossed lychee fruits produced in adjacent blocks of 'Mauritius' and 'Floridian' (Stern et al., 1993). This study extends the number of useful isozyme systems in lychee, and helps to identify lychee cultivars in the Israeli germplasm collection.

\section{Materials and Methods}

Electrophoretic assays. Leaf samples were taken from the lychee germplasm collection maintained at the Volcani Center in Bet Dagan, Israel. The enzymes assayed were aconitase (ACO; EC 4.2.1.3), aspartate aminotransferase (AAT; EC 2.6.1.1 ), isocitrate dehydrogenase (IDH; EC 1.1.1.42), leucine aminopeptidase (LAP; EC 3.4.11.1), phosphoglucose isomerase (PGI; EC 5.3.1.9), phosphoglucomutase (PGM; EC 2.7.5.1), shikimate dehydrogenase (SKDH; EC 1.1.1.25), superoxide dismutase (SOD; EC 1.15.1.1),

Received for publication 16 May 1994. Accepted for publication 2.5 Aug. 1994. Contribution from the Agricultural Research Organization. The Volcani Center. Bet Dagan Israel, no. 1350-E, 1994 series. The cost of publishing this paper was defrayed in part by the payment of page charges. Under postal regulations. this paper therefore must be hereby marked advertisene'nt solely to indicate this fact. ${ }^{1}$ Institute of Evolution, Univ. of Haifa, Haifa 31905 , Isratel.

'Dept. of Horticulure, Faculty of Agriculture. The Hebrew Univ. of lerusialem. Rehovot, Israel. and triosephosphate isomerase (TPI; EC 5.3.1.1).

Horizontal $10 \%$ starch gels $(0.6 \mathrm{~cm}$ thick, $15 \mathrm{~cm}$ wide, $17.5 \mathrm{~cm}$ long ) were prepared from Sigma hydrolyzed starch. Enzymes were extracted by crushing pieces of fresh leaves in $0.15 \mathrm{ml}$ of extraction buffet- (Degani and Gazit, 1984). Filter paper wicks $(4 \times 6 \mathrm{~mm}$. Whatman no. 1) were dipped into the Icaf'extracts. The wicks were then removed, lightly blotted, and loaded into a transverse cut in the starch gels. Wicks dipped in bromophenol blue dye solution were also inserted to visualize the migration of the front. Electrophoresis was conducted at $4 \mathrm{C}$. Running conditions. as well as the compositions of the gel and electrode buffers used for resolving the isozymes are listed in Table 1 .

After electrophoresis, gels were sliced horizontally and stained for the appropriate enzyme: ACO, AAT, and IDH (Soltis et al.. 1983), LAP (Degani et al., 1986), PGI (Goldring et al., 1985). PGM and SKDH (Soltis et al., 1983), and TPI (Goldring et al,. 1987). For SOD, $5 \mathrm{mg} \alpha$ - naphthol dissolved in $2 \mathrm{ml}$ acetone were added just before staining to a $50 \mathrm{ml}$ solution of $0.1 \mathrm{M}$ phosphate buffer (pH 7.0) containing $50 \mathrm{mg} N, N$-dimethyl-p-phenelendiamine. For AAT, $1 \%(\mathrm{w} / \mathrm{v})$ soluble polyvinylpyrrolidone (PVP 40) was added to the staining solution to improve clarity of' the gels (Jongedijk et al., 1990).

Data analysis. We defined the genetic distance between a pair of cultivars as the number of different alleles in the nine polymorphic loci. We did not use a computer program for the counting. as here $a b$ is identical to ba and therefore $a b$ and $b c$ differ only by one allele and not by two, as would be recorded by many computer programs. We preferred evaluating this genetic distance 10 counting the presence or absence of phenotypic bands because here wc are dealing with dimeric systems. In such a system, a heterozygote represents a single allele change but creates two new bands, and the distance is misleadingly inflated. The distance matrix appearing in Table 3 was derived directly from Table 2. Standardization, i.e., dividing by the total number of alleles. was unnecessary, as there was no missing data.

The genetic similarity tree was derived by using the UPGMA clustering method from the previously prepared distance matrix, via the cluster program of SPSS (SPSS, 1990). We checked manually for tics in the process of' clustering.

\section{Results and Discussion}

Isozyme systems. Polymorphisms were observed in eight of the nine enzyme systems studied: in one of these, AAT, two polymorphic loci were found (Table 2). Only LAP was monomorphic in all cultivars examined. 
Table 1. Buffer composition and electrophoretic conditions used to resolve lychee isozymes.

\begin{tabular}{|c|c|c|c|}
\hline $\begin{array}{l}\text { Enzyme } \\
\text { resolved }\end{array}$ & $\begin{array}{c}\text { Electrode } \\
\text { buffer }\end{array}$ & $\begin{array}{c}\text { Gel } \\
\text { buffer }\end{array}$ & $\begin{array}{l}\text { Running } \\
\text { conditions }\end{array}$ \\
\hline PGM & $\begin{array}{l}0.3 \mathrm{M} \text { boric acid, } \\
0.07 \mathrm{M} \text { sodium } \\
\text { hydroxide, } \mathrm{pH} 8.2\end{array}$ & $\begin{array}{l}0.076 \mathrm{M} \text { tris. } \\
0.005 \mathrm{M} \text { citric acid, } \\
\text { pH } 8.7\end{array}$ & $50 \mathrm{~mA} / 5 \mathrm{~h}$ \\
\hline IDH, TPI, LAP & $\begin{array}{l}0.04 \text { M citric acid } \\
\text { adjusted with } \\
N \text {-(3-aminopropyl)- } \\
\text { morpholine to } \mathrm{pH} 8.0\end{array}$ & $\begin{array}{l}1 \text { electrode butfer: } \\
19 \text { water }\end{array}$ & $35 \mathrm{~mA} / 4 \mathrm{~h}$ \\
\hline PGI, SKDH & $\begin{array}{l}0.19 \mathrm{M} \text { boric acid. } \\
0.05 \mathrm{M} \text { lithium } \\
\text { hydroxide }\end{array}$ & $\begin{array}{l}1 \text { electrode buffer: } \\
9 \text { of } 0.05 \mathrm{M} \text { tris- } \\
0.008 \mathrm{M} \text { citric acid. } \\
\text { pH } 8.1\end{array}$ & $50 \mathrm{~mA} / 5 \mathrm{~h}$ \\
\hline $\mathrm{ACO}$ & $\begin{array}{l}0.065 \text { M L-histidine } \\
\text { adjusted with citric } \\
\text { acid to } \mathrm{pH} 5.7\end{array}$ & $\begin{array}{l}1 \text { electrode buffer: } \\
6 \text { water: } \\
4 \% \text { sucrose }\end{array}$ & $35 \mathrm{~mA} / 5 \mathrm{~h}$ \\
\hline SOD & $\begin{array}{l}0.065 \mathrm{M} \text { L-histidine. } \\
\text { adjusted with citric } \\
\text { acid to } \mathrm{pH} 6.1\end{array}$ & $\begin{array}{l}1 \text { electrode buffer: } \\
6 \text { water }\end{array}$ & $10 \mathrm{~mA} / 19 \mathrm{~h}$ \\
\hline AAT & $\begin{array}{l}0.065 \mathrm{M} \text { L-histidine } \\
\text { adjusted with citric } \\
\text { acid to } \mathrm{pH} 6.5\end{array}$ & $\begin{array}{l}1 \text { electrode buffer: } \\
6 \text { water }\end{array}$ & $35 \mathrm{~mA} / 3 \mathrm{~h}$ \\
\hline
\end{tabular}

PGI activity was detected in two zones of the zymogram: PGI1 (most anodal) was monomorphic, while PGI-2 was polymorphic and seven phenotypes were revealed, two homozygous (aa, bb) and five heterozygous (ab, be, cf, cd, ag) (Table 2, Figs. 1 and 2).

Two zones of activity were found in the IDH zymogram. The fastest migrating zone (IDH-1) was polymorphic, having two phenotypes, one with a single band and the other with three bands distributed at regular intervals between $\mathrm{Rf} 0.30$ and 0.38 (Fig. 1). IDH-2 migrated as a single band at Rf 0.27.

In the TPI zymogram, three zones of activity were detected (Fig. 2). TPI-1 and TPI-2 were resolved as single bands at Rf 0.64 and 0.54 , respectively. TPI-3 was polymorphic, exhibiting two phenotypes, one with a single band and the other with three regularly spaced bands ranging from Rf 0.40 to 0.49 (Fig. 1). When the stained gels were left overnight subbands appeared in the space between TPI-1 and TPI-2.

Three zones of activity were observed in gels stained for AAT. AAT-1 was monomorphic and was resolved as a single band (Rf 0.50). AAT-2 was polymorphic with three phenotypes: one with a single band (cc) and two with three bands (ac and bc) (Fig. 1). AAT-3 showed either single-(aa) or triple-band (ah) patterns (Fig. I). All cultivars studied had the aa phenotype, except for 'Kwai May Red' which had the ah phenotype.

For ACO, a single region of activity was found with six phenotypes, two homozygous (aa, cc) and four heterozygous (ac, ad, ae, de) (Fig. 3).

With PGM, only the most anodal zone of activity, PGM-1, was adequately resolved. exhibiting clear and consistent bands. PGM1 was polymorphic and exhibited a single-banded phenotype (aa) and two double-banded phenotypes (ac and ab) (Fig. 3),

SKDH was well resolved as one zone of enzyme activity with two single-banded phenotypes (aa and cc) and two double-handed phenotypes (ac and bc) (Figs, 2 and 3).

One zone of enzyme activity was observed when gel slices were assayed for SOD activity. Two single-banded phenotypes (aa and cc) and two double-banded phenotypes (ac and ah) were scored.

The quarternary structure of enzymes in plant species has remained highly conserved throughout biochemical evolution. especially for those enzymes catalyzing steps in primary metabolism (Gottlieb, 1982: Weeden and Wendel, 1989). This allows an a priori assumption of the quaternary structure of the enzymes assayed (Weeden and Wendel, 1989). For most enzymes. the genetic controls are well enough known to allow genetic inferences to be made from gel isozyme patterns (Murphy et al., 1990), The structures of the isozymes of AAT, IDH, PGI, and TPI have been shown to be dimeric in many other plant species (Kephart, 1990: Weeden and Wendel, 1989). The respective lychee isozymes exhibited phenotypes characteristic of this dimeric structure. Thus, in the triple banded phenotypes the intermediate band exhibited mobility equal to the average mobility of the two extreme bands and its intensity was twice as high (Fig. 2). These symmetrical isozyme patterns with the relative intensities of bands are consistent with theoretical expectations for a heterozygote controlled by two alleles, The banding patterns of AAT-3. IDH-1, and TPI-3 indicate a dimeric structure encoded by two alleles. For AAT-2 and PGI-2, the banding pattern indicates a dimeric structure encoded by three and seven alleles, respectively. ACO, PGM, SKDH, and SOD are known to be monomeric enzymes in plants (Kephart, 1990: Weeden and Wendel, 1989). In the present study. the handing patterns of these enzymes support their monomeric structure.

In many cultivated trees, that are vegetatively propagated, high levels of heterozygosity are known to occur. In our simple, the range of heterozygosity (Table 2) was between 0 and 0.333 (five heterozygote in the 15 loci recorded). Only one cultivar, 'Salathiel', exhibited no heterozygosity in the loci tested, 'Brewster', and its equivalent 'Floridian', displayed the highest estimate of heterozygosity in our sample. Ho $=0.333$

Charaterization of lychee cultivars. Lychee cultivar nomenclature in its present state suffers from many inconsistencies: the same cultivar may be known under several names and different cultivars may appear under the same name. For example, the cultivar 'Fay Zee Siu' (China) appears In Taiwan under the name 'Yu Her Pau' (Menzel and Smpson, 1990) and the cultivar 'Emperor' (Florida) is called 'Chakrapad' in Thailand (Subhadrabandhu, 1990). Isozyme analysis of these cultivars 


\begin{tabular}{|c|c|c|c|c|c|c|c|c|c|c|c|c|}
\hline \multirow[b]{2}{*}{ No. } & \multirow[b]{2}{*}{ Cultivar } & \multirow[b]{2}{*}{ Source $^{z}$} & \multicolumn{9}{|c|}{ Isozyme } & \multirow[b]{2}{*}{$\mathrm{Ho}^{y}$} \\
\hline & & & AAT-2 & AAT-3 & $\mathrm{ACO}$ & IDH- 1 & PGI-2 & PGM-1 & SKDH & SOD & TPI-3 & \\
\hline$\overline{1}$ & Bengal & Florida & $\mathrm{cc}$ & aa & $\mathrm{ad}$ & $\mathrm{bb}$ & cf & aa & $\mathrm{cc}$ & $\mathrm{ac}$ & aa & 0.200 \\
\hline 2 & Bengali & India & $\mathrm{cc}$ & aa & $\mathrm{cc}$ & $\mathrm{bb}$ & aa & $a b$ & $\mathrm{ac}$ & $\mathrm{ac}$ & aa & 0.200 \\
\hline 3 & Black Leaf & Florida & $\mathrm{cc}$ & aa & $\mathrm{cc}$ & $\mathrm{bb}$ & aa & $a b$ & $\mathrm{ac}$ & $\mathrm{ac}$ & aa & 0.200 \\
\hline 4 & Brewster & Florida & $\mathrm{cc}$ & aa & $\mathrm{ac}$ & $\mathrm{bb}$ & $\mathrm{bb}$ & $\mathrm{ac}$ & $\mathrm{ac}$ & $\mathrm{ac}$ & $a b$ & 0.333 \\
\hline 5 & Chakrapad & Australia & $\mathrm{bc}$ & aа & $\mathrm{cc}$ & $a b$ & $\mathrm{bb}$ & aa & $\mathrm{cc}$ & aa & $a b$ & 0.200 \\
\hline 6 & Early Large Red & Florida & $\mathrm{cc}$ & aа & $\mathrm{cc}$ & $\mathrm{bb}$ & aa & $a b$ & $\mathrm{ac}$ & $\mathrm{ac}$ & aa & 0.200 \\
\hline 7 & Emperor & Florida & $\mathrm{bc}$ & aa & $\mathrm{cc}$ & $a b$ & $\mathrm{bb}$ & aa & $\mathrm{cc}$ & aa & $a b$ & 0.200 \\
\hline 8 & Fay Zee Siu & Australia & $\mathrm{ac}$ & aa & $\mathrm{cc}$ & $\mathrm{bb}$ & $\mathrm{cf}$ & ac & $\mathrm{ac}$ & $\mathrm{cc}$ & aa & 0.267 \\
\hline 9 & Floridian & California & $\mathrm{cc}$ & aа & $\mathrm{ac}$ & $\mathrm{bb}$ & $\mathrm{bb}$ & $\mathrm{ac}$ & $\mathrm{ac}$ & $\mathrm{ac}$ & $a b$ & 0.333 \\
\hline 10 & Garnet & Florida & $\mathrm{bc}$ & aа & ae & $\mathrm{bb}$ & $\mathrm{cd}$ & aa & $\mathrm{ac}$ & aa & aa & 0.267 \\
\hline 11 & Groff & Hawaii & $\mathrm{cc}$ & aa & $\mathrm{ac}$ & $\mathrm{bb}$ & $a b$ & aa & aa & $\mathrm{ac}$ & aa & 0.200 \\
\hline 12 & Haak Yip & Hawaii & $\mathrm{bc}$ & aа & $\mathrm{cc}$ & $\mathrm{bb}$ & ag & aa & $\mathrm{ac}$ & $a b$ & aa & 0.267 \\
\hline 13 & Haak Yip 9285 & South Africa & $\mathrm{ac}$ & aа & $\mathrm{cc}$ & $\mathrm{bb}$ & $\mathrm{cf}$ & $\mathrm{ac}$ & $\mathrm{ac}$ & $\mathrm{cc}$ & aa & 0.267 \\
\hline 14 & HLH Mauritius & South Africa & $\mathrm{cc}$ & aа & $\mathrm{cc}$ & $\mathrm{bb}$ & aa & $a b$ & $\mathrm{ac}$ & $\mathrm{ac}$ & aa & 0.200 \\
\hline 15 & Hong Huay & Thailand & $\mathrm{cc}$ & aа & $\mathrm{cc}$ & $\mathrm{bb}$ & aa & $a b$ & $\mathrm{ac}$ & $\mathrm{ac}$ & aа & 0.200 \\
\hline 16 & Kaimana & Hawaii & $\mathrm{cc}$ & aа & $\mathrm{cc}$ & $\mathrm{bb}$ & ag & aa & $\mathrm{ac}$ & $a b$ & aa & 0.200 \\
\hline 17 & Kwai May Pink & Australia & $\mathrm{cc}$ & aa & de & $\mathrm{bb}$ & $a b$ & aa & $\mathrm{cc}$ & aa & aa & 0.133 \\
\hline 18 & Kwai May Red & Australia & $\mathrm{cc}$ & $a b$ & de & $\mathrm{bb}$ & be & aa & $\mathrm{bc}$ & aa & aa & 0.267 \\
\hline 19 & Kwai Mi & Hawaii & $\mathrm{cc}$ & aа & $\mathrm{cc}$ & $\mathrm{bb}$ & aa & $a b$ & $\mathrm{ac}$ & $\mathrm{ac}$ & aa & 0.200 \\
\hline 20 & Late Seedless & Hawaii & $\mathrm{bc}$ & aa & $\mathrm{cc}$ & $\mathrm{bb}$ & aa & aa & $\mathrm{ac}$ & aa & $a b$ & 0.200 \\
\hline 21 & Mauritius & South Africa & $\mathrm{cc}$ & aа & $\mathrm{cc}$ & $\mathrm{bb}$ & aa & $a b$ & $\mathrm{ac}$ & $\mathrm{ac}$ & aa & 0.200 \\
\hline 22 & No Mai Chee & Hawaii & $\mathrm{cc}$ & aa & $\mathrm{cc}$ & $a b$ & be & aa & $\mathrm{cc}$ & aa & aa & 0.133 \\
\hline 23 & Red McLean & South Africa & $\mathrm{cc}$ & aа & ad & $\mathrm{bb}$ & $a b$ & aa & $\mathrm{cc}$ & $\mathrm{ac}$ & aa & 0.200 \\
\hline 24 & Sah Keng & Taiwan & $\mathrm{cc}$ & aa & $\mathrm{ac}$ & $\mathrm{bb}$ & $a b$ & aa & aa & aa & aa & 0.133 \\
\hline 25 & Salathiel & Australia & $\mathrm{cc}$ & aa & aa & $\mathrm{bb}$ & $\mathrm{bb}$ & aa & $\mathrm{cc}$ & aa & aa & 0.0 \\
\hline 26 & Souey Tung & Australia & $\mathrm{ac}$ & aа & $\mathrm{cc}$ & $\mathrm{bb}$ & ag & aa & $\mathrm{ac}$ & $\mathrm{ac}$ & aa & 0.267 \\
\hline 27 & Sum Yee Hong & Australia & $\mathrm{ac}$ & aa & $\mathrm{cc}$ & $\mathrm{bb}$ & $\mathrm{cf}$ & $\mathrm{ac}$ & $\mathrm{ac}$ & $\mathrm{cc}$ & aa & 0.267 \\
\hline 28 & Wai Chee & Australia & $\mathrm{bc}$ & aa & ae & $\mathrm{bb}$ & $\mathrm{cf}$ & aa & $\mathrm{cc}$ & aa & aa & 0.200 \\
\hline 29 & Yu Her Pau & Taiwan & $\mathrm{ac}$ & aа & $\mathrm{cc}$ & $\mathrm{bb}$ & $\mathrm{cf}$ & $\mathrm{ac}$ & $\mathrm{ac}$ & $\mathrm{cc}$ & aa & 0.267 \\
\hline 30 & $\# 3$ & Taiwan & $\mathrm{bc}$ & aa & $\mathrm{cc}$ & $\mathrm{bb}$ & ag & aa & $\mathrm{ac}$ & $a b$ & aa & 0.267 \\
\hline
\end{tabular}

${ }^{7}$ Country from which the cultivar was introduced to Israel.

'Observed heterozygosity.

showed identical zymograms for 'Fay Zee Siu' and 'Yu Her Pau', and for 'Emperor' and 'Chackrapad', for all enzyme systems examined (Table 2).

In our lychee germplasm repository at the Volcani Center, Bet Dagan, we have found that 'Mauritius', the main Israeli commercial cultivar, is morphologically very similar to six other cultivars introduced from various parts of the world under different names. These are 'Bengali' (from India), 'Early Large Red' [Indian cultivar introduced from U.S. Dept. of Agriculture (USDA) Miami], 'Hong Huay' (from Thailand), 'Kwai Mi' (Chinese cultivar introduced from Hawaii), 'Black Leaf' (from USDA Miami), and 'HLH Mauritius' (from South Africa). The great morphological similarity and the identical isozyme profile (Table 2) suggests that all seven cultivars may be identical.

'Souey Tung' is often confused with 'Haak Yip' (Menzel and Simpson, 1986). Although the former can be distinguished from 'Haak Yip' by its slightly earlier maturity and by minor differences in fruit weight and shape (Batten, 1984), these features cannot be used to identify young plants. However, young plants of these cultivars can be easily distinguished on the basis of their different AAT and SOD banding patterns (Table 2). For both of these enzymes, 'Souey Tung' exhibited ac phenotypes, whereas 'Haak Yip' exhibited the phenotypes bc and ab, respectively.

'Fay Zee Siu' is mistakenly named 'Haak Yip' in different countries (Galan-Sauco and Menini, 1989). It can be readily distinguished from the latter by isozyme analysis of the systems

\section{AAT, PGI, PGM, and SOD (Table 2).}

In Australia, several imports of 'Kwai May Red' (from Hong Kong and United States) were sold and planted as 'No Mai Chee' (Batten, 1984). The misnaming was revealed when the trees came into production. This confusion could have been avoided before planting by isozyme analysis of the systems ACO, AAT, IDH, and SKDH (Table 2). Similarly, there has been some confusion over 'Groff' and 'Haak Yip' in Australia (Watson, 1983). These two cultivars can be distinguished by analyzing AAT, ACO, PGI, SKDH, and SOD (Table 2).

Trees of 'Kwai May Red' resemble those of 'Kwai May Pink' but the two cultivars differ in fruit color (Menzel and Simpson, 1986). This difference can only be discerned in adult trees, pre-

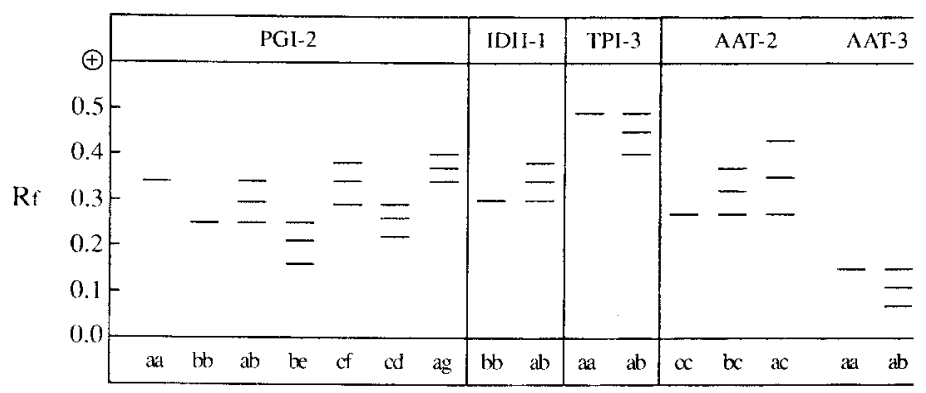

Fig. 1. Schematic zymograms of representative phenotypes for PGI, IDH, TPI, and AAT isozymes in lychee. Relative mobility (Rf) on the left. 

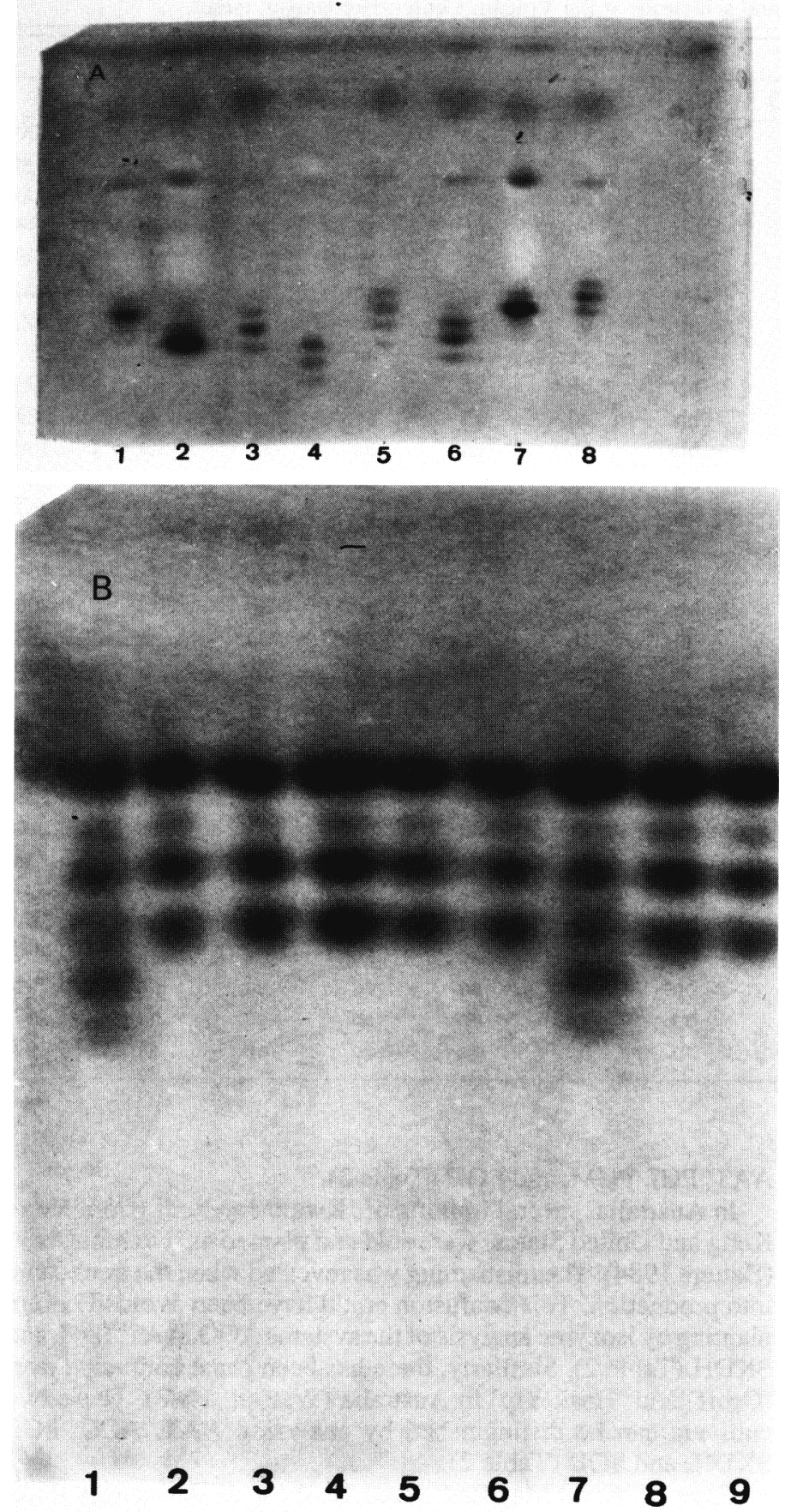

eluding its use as an identifying characteristic in young plants. Isozyme analysis of AAT, PGI, and SKDH can verify identification of young plants of these cultivars (Table 2).

Isozyme analysis was used to ascertain the identity of 'Haak Yip' obtained from several sources. 'Haak Yip' was introduced to Israel from Hawaii in 1975. Later, 'Haak Yip' was introduced from South Africa (Israeli Plant Introduction number 9285) and also from Florida under the name 'Black Leaf' (Goren and Gazit, 1994). 'Haak Yip 9285', 'Black Leaf' and 'Haak Yip' were found to be isozymically different (Table 2). Only the 'Haak Yip' introduced from Hawaii resembles the 'Haak Yip' described in the literature (Batten, 1984; Groff, 1921).

We introduced an unnamed cultivar from Taiwan under the code selection \#3. It closely resembles the Hawaiian 'Haak Yip' in

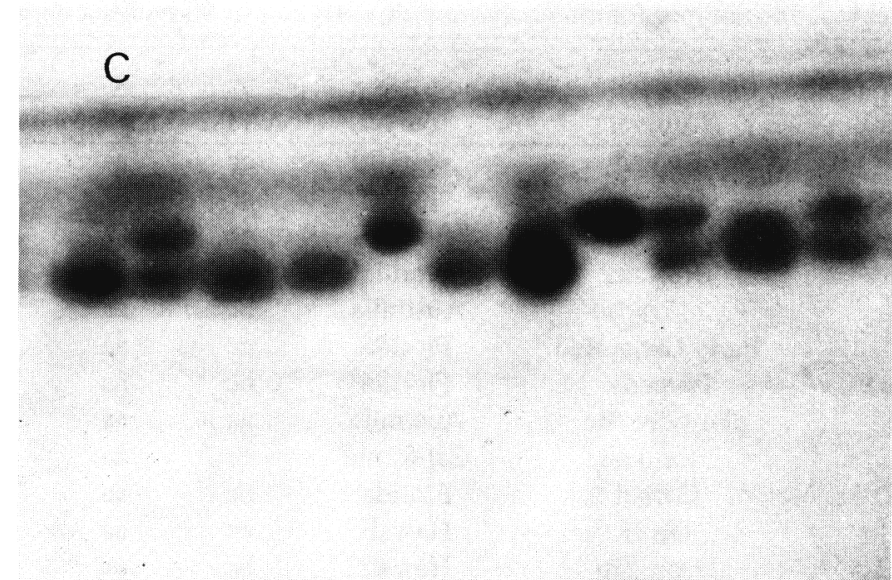

\section{$\begin{array}{lllllllllll}1 & 2 & 3 & 4 & 5 & 6 & 7 & 8 & 9 & 10 & 11\end{array}$}

Fig. 2. Variation in (A) PGI, (B) TPI, and (C) SKDH isozymes in lychee leaf extracts. The sequence of cultivars for PGI is 1) 'Mauritius', 2) 'Floridian', 3) 'Sah Keng', 4) 'Kwai May Red', 5) 'Fay Zee Siu', 6) 'Garnet', 7) 'Early Large Red', 8) 'Kaimana'. The sequence for the TPI gel is 1) 'Floridian', 2) 'Mauritius', 3) 'Kaimana', 4) 'No Mai Chee', 5) 'Garnet', 6) 'Bengal', 7) 'Late seedless', 8) 'Early Large Red', 9) 'Haak Yip'. The sequence for the SKDH gel is 1) 'No Mai Chee', 2) 'Sum Yee Hong', 3) 'Red McLean', 4) 'Bengal', 5) 'Groff', 6) 'Kwai May Pink', 7) 'Wai Chee', 8) 'Sah Keng', 9) 'Haak Yip', 10) 'Kwai May Red', 11) 'Brewster'.

tree and fruit characteristics, suggesting that these two cultivars are identical. The isozymic data strongly support this suggestion.

The Israeli cultivars 'Bengal' and 'Bengali' have been reported to be 'Kwai Mi' and 'Kwai May Red', respectively (Galan-Sauce and Menini, 1989). This information is incorrect, as can be readily observed by their morphological traits as well as by isozymic analysis (Table 2). 'Bengal' was introduced from the U.S. Dept. of Agriculture Research Station in Miami, while 'Bengali' was introduced to Israel from Bengal, India in 1939. 'Bengali' very much resembles the cultivar 'Mauritius' in all morphological traits. The isozymic data support the possibility that they may be the same cultivar.

The suggested hybrid origin of some lychee cultivars can be supported or refuted on the basis of their isozyme phenotypes. 'Salathiel' has been suggested to be an offspring of 'No Mai Chee' (Batten, 1984). However, isozyme analysis by ACO does not support this possibility, since 'Salathiel' has the aa phenotype, and 'No Mai Chee' the cc phenotype.

'Sah Keng', 'Groff', and 'Kaimana' were reported to be offsprings of 'Haak Yip' (Menzel and Simpson, 1990). The isozymic banding patterns of these cultivars support their origin from 'Haak Yip' by cross-pollination (Table 2).

Genetic similarity among lychee cultivars. Five groups of cultivars were identical in all 15 allozymic loci tested. Each group was therefore represented in the distance matrix (Table 3) and in the similarity tree (Fig. 4) by only one of its cultivars. Thus, 'Mauritius' represents 'Bengali', 'Black Leaf', 'Early Large Red', 


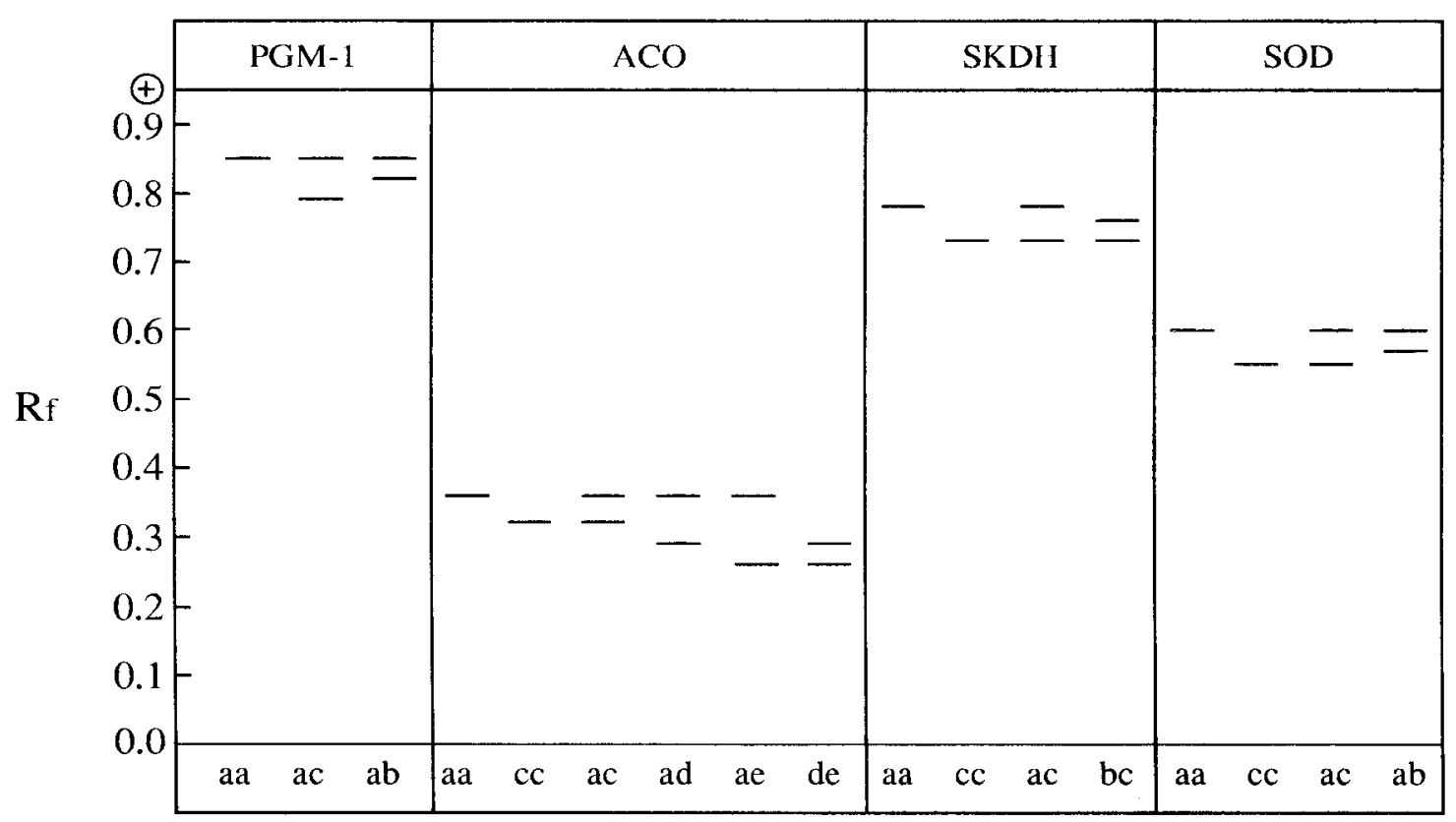

Fig. 3. Schematic zymograms of representative phenotypes for PGM, ACO, SKDH, and SOD isozymcs in lychee. Relative mobility (Rt) on the left

'Hong Huay', 'HLH Mauritius', and 'Kwai Mi'; 'Fay Zee Siu' represents 'Haak Yip 9285', 'Sum Yee Hong'. and 'Yu Her Pau'; 'Haak Yip' represents \#3; 'Brewster' represents 'Floridian', and 'Chakrapad' represents 'Emperor'. The 18 nonequivalent cultivars appear in the distance matrix.

The distance is defined as the number of allelic differences between each pair of cultivars. Those values are recorded in Table 3 . The maximal distance was between 'Kwai May Red' and the group of 'Fay Zee Siu': 10 allelic changes. Only two pairs differed by a single change: 'Groff'-'Sah Keng' and 'Kaimana'-'Haak Yip'.

It should be noted that this distance measure treats all allozymic differences equally. An allozymic change can occur by mutation (a rare event), by segregation (a common event, but only when the tree is grown from seed), and after hybridization (outcrossing with a different cultivar). Even after those events, the breeder exercises strong selection and consequently, no probabilistic calculations are applicable. We, therefore based outdistance matrix on a simple dissimilarity measure, by counting the allelic differences.

The distance matrix shown in Table 3, was analyzed by the cluster program of the SPSS package (SPSS, 1990). We used the UPGMA method. This method produces usually a single tree, if no ties are encountered. The tree is grouping (clustering) first the most similar cultivars and proceed stepwise to combine, at each step, the most similar cultivars or clusters of cultivars. The tree appear in Fig.4.

We checked the tree forties. We encountered two ties. The first tie was between the pairs 'Kwai May Pink'-'Red McLean' and 'Bengal '-'Red McLean'. Both pairs differed by two allozymic alleles. The program randomly chose to cluster ' Kwai May Pink'

Genetic Distance (Number of Allozymic Differences)

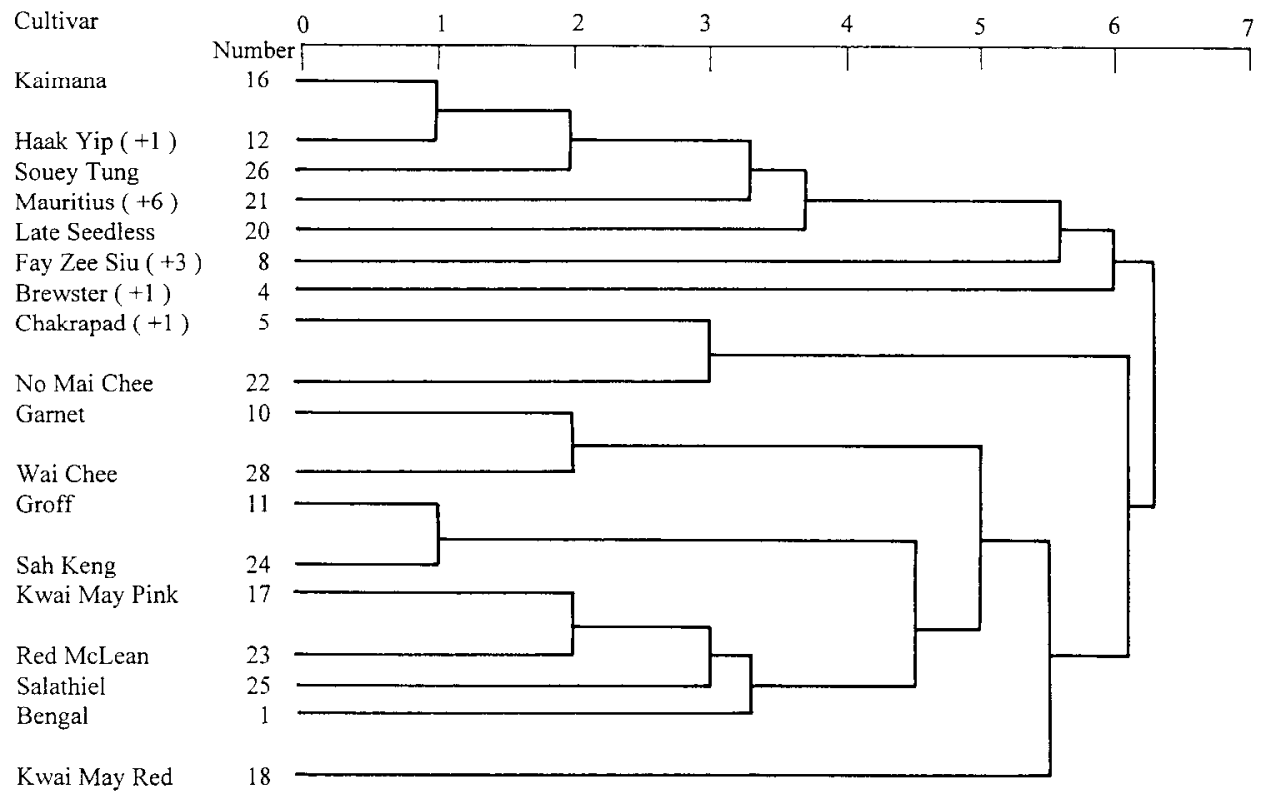

Fig. 4. An electrophoretic similarity tree of 18 nonequivalent lychcc cultivars, constructed using UPGMA based on the distance matrix of Table 3. Branch lengths are given as average number of differences in electrophoretic alleles. 
Table 3. Electrophoretic distance matrix between 18 nonequipment lychee cultivars.

\begin{tabular}{|c|c|c|c|c|c|c|c|c|c|c|c|c|c|c|c|c|c|c|c|}
\hline & Cultivar & 1 & 4 & 5 & 8 & 10 & 11 & 12 & 16 & 17 & 18 & 20 & 21 & 22 & 23 & 24 & 25 & 26 & 28 \\
\hline$\overline{1}$ & Bengal & 0 & & & & & & & & & & & & & & & & & \\
\hline 4 & Brewster +1 & 6 & 0 & & & & & & & & & & & & & & & & \\
\hline 5 & Chakrapad +1 & 8 & 6 & 0 & & & & & & & & & & & & & & & \\
\hline 8 & Fay Zee Siu +3 & 6 & 6 & 9 & 0 & & & & & & & & & & & & & & \\
\hline 10 & Garnet & 5 & 7 & 7 & 7 & 0 & & & & & & & & & & & & & \\
\hline 11 & Groff & 5 & 4 & 8 & 7 & 6 & () & & & & & & & & & & & & \\
\hline 12 & Haak Y ip +1 & 7 & 7 & 6 & 6 & 5 & 5 & 0 & & & & & & & & & & & \\
\hline 16 & Kaimana & 6 & 6 & 7 & 6 & 6 & 4 & 1 & 0 & & & & & & & & & & \\
\hline 17 & Kwai May Pink & 4 & 7 & 6 & 9 & 5 & 5 & 6 & 5 & 0 & & & & & & & & & \\
\hline 18 & Kwai May Red & 6 & 8 & 8 & 10 & 6 & 7 & 8 & 7 & 3 & 0 & & & & & & & & \\
\hline 20 & Late Seedless & 8 & 6 & 4 & 7 & 5 & 6 & 3 & 4 & 6 & 8 & 0 & & & & & & & \\
\hline 21 & Mauritius +6 & 6 & 5 & 8 & 5 & 7 & 4 & 4 & 3 & 6 & 8 & 4 & 0 & & & & & & \\
\hline 22 & No Mai Chee & 6 & 7 & 3 & 8 & 7 & 6 & 6 & 5 & 4 & 5 & 6 & 6 & 0 & & & & & \\
\hline 2.3 & Red McLean & 2 & 5 & 7 & 8 & 6 & 3 & 6 & 5 & 2 & 5 & 7 & 5 & 5 & 0 & & & & \\
\hline 24 & Sah Keng & 6 & 5 & 7 & 8 & 5 & 1 & 5 & 4 & 4 & 6 & 5 & 5 & 5 & 4 & 0 & & & \\
\hline 25 & Salathiel & 4 & 5 & 5 & 9 & 5 & 5 & 7 & 6 & 3 & 5 & 7 & 7 & 4 & 3 & 4 & 0 & & \\
\hline 26 & Soucy Tung & 6 & 6 & 7 & 4 & 6 & 4 & 2 & 2 & 6 & 8 & 4 & 3 & 6 & 5 & 5 & 7 & 0 & \\
\hline 28 & Wai Chee & 3 & 8 & 6 & 7 & 2 & 7 & 6 & 7 & 4 & 6 & 6 & 8 & 6 & 5 & 6 & 4 & 7 & 0 \\
\hline
\end{tabular}

${ }^{2}$ The distance is measured as the number of allelic differences in the 15 loci studied. Each group of electrophoretically identical cultivars is represented by one cultivar from the group. The number of hidden cultivars appears as a plus next to the name.

with 'Red McLean', and to ignore 'Bengal'. If we try the alternative, only the internal order within the branch of 'Kwai May Pink', 'Red McLean', 'Salathiel' and 'Bengal' is altered. That does not change any conclusion drawn from the tree. The second tie is between 'Sah Keng' and 'Groff' with either 'Brewster' or the cluster of 'Bengal', 'Kwai May Pink', 'Red McLean', and 'Salathiel'. Both distances are of 4.5 allozymic changes. The computer ignored 'Brewster'. which latter, at the distance of 6.0 changes. joints an alternative cluster. The two alternative equivalent paths of clustering, combine 'Brewster' into entirely different clusters of cultivars. Therefore, the position of 'Brewster' in the tree must be regarded as dubious.

The similarity tree reveals two large groups and three independent pairs: Group I consists of 'Haak Yip', 'Kaitnana', 'Souey Tung', 'Mauritius' (and its six equivalent cultivars), and 'Late Seedless. Group 2 consists of 'Kwai May Pink', 'Red McLean', 'Salathiel', and 'Bengal'. Group 3 is the pair 'Groff'-'Sah Keng'. Group 4 is 'Garnet'-'Wai Chee' and Group 5 is 'No Mai Chee''Chakrapad' (including 'Emperor').

Three cultivars differ from all existing groups with more than five changes. Those are 'Fay Zee Siu' (including its three equivalent cultivars), 'Brewster' (including 'Floridian'), and 'Kwai May Red'. Those similarities are weak and maybe dubious, as has been shown earlier for 'Brewster', especially when more information will be added from more genetic loci or additional molecular genetic markers. Moreover. in our distance matrix we gave equal weighing to all possible changes and no probability estimate was applicable, Therefore. it is important to regard this tree as the first evolutionary estimate, which must be verified and complemented by additional genetic studies of more systems. Of particular interest would be a mtDNA analysis, which reveals the female phylogenetic relations. A comparison with the electrophoretic tree will indicate cases of hybridization.

This study demonstrates the utility of isozyme analysis in reducing the cinfusion overly lychee cultivar names. Regular isozyme analysis of lychee cultivars held by germplasm repositories is now feasible and advisable for early detection of cultivar mislabeling. Isozymes should also prove to be a useful tool for identification of nursery plants

\section{Literature Cited}

Batten, D. 1984 Ag-Fact H6.2.7. 1-15 Dept. of Agr., New South Wales.

Degani, C. and A. Blumenfeld. 1986 The use of isozymc analysis for differentiation between loquat cultlvars. HortScience 21:1457-1458.

Degani, C., R. E1-Batsri, and S. Gazit, 1990. Enzyme polymorphism in mango. J. Amer. Soc. Hort Sci. 115:844-847.

Degani, C. and S. Gazit. 1984. Selfed and crossed proportions of avocado progenies produced by caged pairs of complementary cultivars. HortScience 15:258-260.

Degani, C., A. Goldring, S Gazit. and U. Lavi. 1986. Genetic selection during the abscission avocado fruitlets. HortScience 21:1187-1188.

Galan-Sauco, V. and U.G. Menini. 1989. Litchi cultivation. FAO Plant Prod. Protection Paper 83 Goldring, A., S. Gazit. and C. Degani. 1987 Isozyme analysis of mature avocado embryos to determine outcrossing rate in 'Hass' plot J. Amer Soc. Hort Sci. 112:389-392.

Goldring, A., D. Zamir, and C. Degani. 1985 Duplicated phosphuglucose isomerase genes in avocado. Theoretical Applied Genet. 71:451-454

Goren, M. and S. Gazit. 1994. New promising lychee cultvars for Israel in 1993-Description, evaluation and recommendations. Alon haNotea 48:202-206.

Gottlieb, D. 1982. Conservation and duplication of isozymes in plants. Science 216:373-380.

Groff, G.W 1921. The lychee and lungan. Orange Judd Co., New York. p 95.

Jongedijk, E., J.M.A.S.H. Van der Wolk, and L.C.J.M Suurs. 1990 Analysis of glutamate oxidoacetate transaminase (GOT) isozyme variants in diplold tuberous Solanum; inheritance and linkage relationships to ds1 (desynapsis), Y (tuber flesh colour), cr (crumpled) and yc (yellow cotyledon). Euphytica 45:155-167.

Kephart, S.R 1990. Starch gel electrophoresis of plant isozymes: A comparative analysis of techniques, Amcr J. Bot 77:693-712.

Knight, Jr., R. 1980. Origin and world importance of tropical and subtropical fruit crops, p. 1-20. In: S. Nagy and P.E Shaw (eds.) Tropical and subtropical fruits. AVI, Westport, Corm.

Menzel, C.M. and D R. Simpson 1986. Description and performance of major lychee cultvars in subtropical Queensland Queensland Agr. J. 112:125-136.

Menzel, C.M. and D.R. Simpson 1990. Performance and improvement of lychee cultivars: A review. Fruit Var. J. 44:197-215.

Messina, R., R Testolin, and M Morgante 1991. Isozymes for cultivar identification in kiwifruit. HortScience 26:899-902

Murphy, R W., J.W Sites, Jr., D.C. Buth. and C.H. Hautler. 1990. Proteins I. Isozyme electrophoresis, p 45-126. In: D.M Hillis and C. Moritz (eds.), Molecular systematics. Sinauer Assoc., Sunderland Nielsen, G. 1985. The use of isozymes as probes to identify and label plant varieties and cultivars, $p$ 172 In M.C Rattazzi, J.G. Scandalios, and G.S. Whitt (eds). Isozymes: Current topics in biological and medical research. vol. 12. Alan R. Liss, New York.

Parfitt, D.E. and S. Arulsekar 1989. Inheritance and isozyme diversity for GPI and PGM among grape cultivars, J. Amer. Soc. Hort. Sci. 114:486-491

Soltis, D. E., C.H. Hauffer, D.C Darrow. and G.J. Gastony. 1983. Starch gel electrophorsis of ferns: A compilation of grinding buffers, gel and electrode buffers, and straining, schedules. Amer. Fern. J 73:9-27.

SPSS 1990 SPSS reference guide, release 4. SPSS. Chicago.

Stern, R. A., S Gazit, R. El-Batsri, and C. Degani. 1993 Pollen parent effect on outcrossing rate, yield and fruit characteristics of 'Floridian' and 'Mauritius' lychee. J. Amer Soc Hort Sci. 118: 109-114 Subhadrabandu, S. 1990. Lychee and Longan cultivation in Thailand. Rumthai Publication. Bangkok.

Torres, A.M. and B.O. Bergh 1980. Fruit and leaf Isozymes as genetic markers in avacado J. Amer. Soc Hort. Sci. 105:614-619

Watson, B.J. 1983. I.ychee-Cultivar name. AGDEX 238/33 Queensland Dept. of Primary Inds Britsbane.

Weeden, N.F. and R.C. Lamb, 1985 Identification of apple cultivars by isozyme phenotype J Amer. Soc. Hort. Sci. 110:500-515

Weeden, N.F. and J.F. Wendel. 1989. Genetics plant isozymes, p.46-72 In D.F Soltis and P.S Soltis (eds.) Isozymes in plant biology Dioscorides Press, Portland 